\title{
Social and Political Theory of Social Movements for the Social State
}

\section{Dr. Stefanos Koffas}

\author{
Department of Business Administration, \\ Technological Educational Institute of Thessaly,
} Larissa-Greece

\author{
Doi: $10.2478 / \mathrm{mjss}-2019-0001$
}

\begin{abstract}
Social movements, as collective entities, develop to stand up against the existing institutional status quo with a view to its reformation or radical transformation, while the degree to which they are political depends on wider socio-political factors. The diverse action that evolved through their organized mobilization marked the radical transformation of political response, but also the type of state intervention. Social movements exactly because they constitute wider socio-political undertakings that aim to bring about changes in the social, political, economic but also cultural processes, which seek to annul or sideline established standardizations, are considered one of the most readily available ways to express political and social claims; here they are understood to be dynamic interventions in institutionally and structurally complete social systems as in the case of the social state. Within the context of political mobilization and collective social action, social movements functioned at two interrelated levels: the level of expansion, but also of redefinition of social intervention processes in order to achieve the goals of the social state, and the cultural level, a symbolic promotion, in order to establish a greater degree of social justice. Mobilization of resources, collective behaviour for making claims, even contentious action and transaction with institutions and authorities, constitute views of social transformation and political process in the context of the creation and development of the social state.
\end{abstract}

Keywords: political theory, social theory, social movements, social state, collective action

\section{Social Movements ${ }^{1}$ and the Creation of the Social State}

Legislative state intervention in the social sector may be explained as the result of a series of different historical developments and social changes, with the organization of mass production at an industrial level being the most important. The first legislatively established official state intervention in social life by means of specific measures, with the institution of labour rights, can be traced to $19^{\text {th }}$ century Germany in response to social problems and working conditions (Schmidt, in: Schäfers/Zapf, 1998). The concept of setting up the early social state brought changes in the prevalent understanding of the state's role, as until then the responsibility for social, economic and cultural development of society was in the hands of the citizens themselves. Due to the adverse working conditions and deprived living circumstances of a large part of the productive masses the state had to take action in the social sector as well, in order to redress social injustices and especially to bring some balance in regard to their standard of living, and hygiene and living conditions. The inability of informal networks and the fragmented until then guilds to respond

\footnotetext{
${ }^{1}$ The concept of social movements encompasses the combination of three elements: a) sustained demands against the authorities, b) innovative collective actions and rituals, such as the founding of organizations, and c) collective evidence of worthiness, unity, numbers and commitment (Tilly, 2004, p. 5).
} 
effectively led to demands for measures for the protection and safety of workers; collective actions and the mobilization of the workers' movement were organized to this end, while trying to gain the support of political powers and centres of power (Informationen zur politischen Bildung, 1992). The development, expansion and specialization of those early intervention measures, and the additional struggles and demands that followed, led in their evolution to the creation of the social state as is currently known.

The different theoretical approaches to explaining social intervention in the social sector, as a result of successful labour movement mobilizations, led to a number of parameters which are delimited by specific ideological perspectives and political choices. More specifically, they are linked with the meaning attached to the concept of social state, the intervention model (e.g. liberal, corporatist, socio-democrat), its synergy with the administrative implementation (e.g. rational or ad hoc, based on citizens' needs or not), the manner of implementation (e.g. with or without the participation of social partners in the decision making process), the target group (e.g. the entirety of society or particular vulnerable groups) and the type of interventions it promotes (e.g. circumstantial or reformative institutional changes).

"At the macro level of social approaches, the transformational perspective based on the radical approach (Ledwith, 2006) to collective action and development of intervention measures focuses on the perception of empowerment, of critical consciousness and education of the population" (Koffas, 2016, p. 3). The primary concern in this approach is the mobilization of individuals as rationally thinking citizens, who become motivated, join forces, learn and become trained in demanding their rights even dynamically, endeavouring to overturn existing conditions of deprivation and oppression (Freire, 1985) and at the same time seeking a greater degree of social justice.

Based on the utilization of collective action ${ }^{2}$ as the primary characteristic of social movements the social and political analysis of their significance to the social state is attempted.

\section{The Social and Political Process of Social Movement Theory}

According to Tilly (2004) the "social movement emerged from a consequential synthesis of three elements" (p. 5): a) campaigns: sustained claims that are targeted to the 'authorities' (primarily but not exclusively state ones), b) repertoires: novel collective actions and rituals such as the creation of organizations, the use of media and the circulation of material, and finally c) collective displays of worthiness, unity, numbers and commitment (Tilly, 2004).

The significance of the claims of the social movement in the form of work stoppages and/or absenting from work and at the same time demanding at least basic labour rights acquires a political nature ${ }^{3}$, as it constitutes an expansion of conventional political action forms; at the same time it places the focal point of collective claims within guilds and labour organizations, which operate as collective rational administrators of the movement's resources within a political market so as to achieve concrete goals. The political element though has a clearly wider sense: to change the manner of thinking and the attitude of participants by rousing and mobilizing through collective action, and their representation in organized groups. It also attempts to highlight the prevalent social, political and economic attitudes, values, perceptions, practices and behaviours through the scope of ensuring autonomy; that is the autonomous collective shaping of new social, political and economic conditions based on such values that will ultimately allow attainment of equality and

\footnotetext{
${ }^{2}$ Wright (2009) points out that collective action is an intragroup behaviour, i.e. individuals are carriers of their social identity and are trying to improve the position of the group, and not an individual behaviour where individuals are carriers of their personal identity and are trying to improve their personal standing. It should be pointed out that collective action is not related to how massive participation is nor does it necessarily concern individual collectivities, but is rather related with the goal of the action, i.e. changing the status quo (Wright, 2009).

${ }^{3}$ A movement has a political dimension when it targets the authorities (government, local government, sectors of public administration) in order to force them, through a public intervention, to take a position in regard to a demand; also the blame for the issue at the heart of the mobilization is put on the authorities (Neveu, 2002, pp. 57-59).
} 
social justice. Furthermore, elements of social inter-reaction, i.e. socially and ideologically oriented transaction, negotiation and even struggle criteria, are present among the different social strata, which use various means in order to secure their interests. Additionally, elements of networking and collective identity of participants in social movements - as the basic characteristics of political perspective and action - are to a great extent present and utilize the element of large numbers as a demonstration of strength in their transactions with political adversaries.

Hence, social movements throughout time constitute a distinct political but also "social process that comprises mechanisms through which the actors of collective actions a) become involved in conflict relationships with clearly identified adversaries, b) are linked to dense informal networks, and c) share a distinct collective identity" (della Porta \& Diani 2006, pp. 20-22). Neveu (2002) considers that the defining element of social movements today is the determination of the adversary, such as political authorities, employers, public administration, etc. As he characteristically mentions "there is a characteristic that differentiates this type of collective action (social movements, Ed.) from other ... groups, which try to respond to a problem or claim by searching solely internally for the answer. This type of self-help was especially developed by mutuality movements and cooperatives. The labour movement, farmers and certain parts of the public sector developed an original form of mobilization, in order to develop - through voluntary contributions of members - welfare systems on matters of health, insurance, supply networks for goods and others. With this type of mobilization head-on collision is avoided. The energy and means to create a new status quo are sought within the collectivity" (Neveu, 2002, p. 58) as an alternative solution.

One may observe above that adversarial elements are, in one way or another, present in the political struggle of social movements which include several forms of dynamic confrontation, but also conflict. Della Porta and Diani (2006) explain that political conflict is "an oppositional relationship between actors who seek control of the same stake - be it political, economic or cultural power - and in the process make negative claims on each other - claims which if realized would damage the interests of the other actors" (p. 21). In the case of the labour movement we should seek within the conflict elements - beyond objective working, health and safety conditions, and the prospect of unemployment - the cultural stakes and the changed manner of thinking and attitudes of workers; workers who are transforming from followers of orders to autonomous subjects that have the ability, through collective processes of their elected guilds, to decide the fate of their common undertaking.

According to the theory of resource mobilization ${ }^{4}$ and without overlooking the role of spontaneous, but also conscious action forms in social movements (and in the context of protests too), the issue of power at the material level of wealth distribution and at the level of ideological and political dominance is just as important. In societies with representative political systems, political struggle for resource allocation but also succession to power is a self-evident mobilization characteristic of social groups, usually under the guidance of political ideology. In the case of both conscious and spontaneous mobilization of social groups, the protagonist managing the necessary resources for the mobilization acts politically, presenting the claims of those mobilized, but with political benefit being the ultimate goal. During such periods of crises, dominant elites, in their turn, look to organizations for ways to diffuse discontent ${ }^{5}$. Therefore they either proceed with certain material concessions, e.g. greater dispersion of already established social security benefits, or they appear to be assigning them political or guild-related motives, e.g. pursuing benefit concessions,

\footnotetext{
${ }^{4}$ According to this approach, social protest is a sum of rational collective actions by groups in order to promote their goals and interests, by exerting pressure on those in power to succumb to their demands. Collective action is rather a strategic political choice than an emotional response to injustice (Alexandropoulos, 1995, $p$. 12). Klandermans (1984) proposed that the main element of individuals' incentives when involved in collective actions is the subjective expectation of whether the action will be successful and attain its goals. This leads to the opinion that people proceed with collective action if they consider that it will make the attainment of their goals more likely (perceived efficacy).

${ }^{5}$ Tarrow (1998) classifies collective actions based on their relationship with the recipients of movement claims as follows: a) actions to convince about the justness of the cause, b) transactional and attempting quid pro quo actions, and c) actions creating pressure with the threat of causing harm.
} 
thus looking to transfer the conflict at the institutional level in order to contain the unpredictable outcomes of mass action.

However, the political utilization of collective action per se is not the outcome of mobilization activities of social groups under informal or formal leaders; it rather constitutes an effort to alter the institutional status quo when factors of significant change in the operation of social life and transformational conditions in general are present. The relative political weakness though of social movements to utilize the strength of their numbers cannot be ignored; they become prey to political parties and ideologies that try to win them over for their own gains. The political significance of this point lies in the fact that the way in which claims are expressed are not fully determined by the free will of people: they are mediated by factors such as political mentality of autonomy or guidance, the political institutional framework, but also the cultural environment that the participants live in (Sdrolias, Aspridis, Kakkos, \& Belias, 2013, p. 11). The outcomes of such politically guided actions that use collective movements are characteristically reflected in e.g. claims for pillars of additional insurance, minimum guaranteed income without criteria etc, which serve the political ideology that promotes them.

Social movements as collectivities making claims are part of the institutional operational framework of political struggle and the shaping of social policy as social partners. However, the outcome of their efforts will not necessarily lead to institutional or structural transformation of the range of benefits from the side of the social state. It is supported that "in the framework of the political process theory, there are four types of indications that render a structure of political opportunities positive for the collective actors: a) opening of access to power, b) shifting alignments, c) influential allies, and d) emerging splits between and within elites" (Tarrow, 1998, p. 54).

In any case though, mobilizations put pressure on political elites to make commitments which according to their implementation or not may lead either to changes in the allocation of existing resources and social welfare benefits, or to widening of the protest and the mobilization. In this sense, the course of social movements depends to a great extent on the credibility of political elites, their willingness and ability to bring about changes according to the current operational demands of the situation in hand, as during the past years with changes in insurance, pension, health and welfare systems.

The reactions of the participants in the mobilization are described by political theory as the dimension of political opportunities for those mobilizing, which can affect the course and outcome of social movements, but also the electoral power of political parties. According to McAdam (1996), political opportunity refers to consistent but not necessarily formal or permanent dimensions of the political environment which provide incentives for collective action by affecting people's expectations for success or failure. Certain parameters that shape political opportunities are the degree to which the political system and decision centres are open or closed, i.e. allow access to new actors, the availability of allies, rifts within the dominant elite, the state's suppressive capacity and will, the stability of political alignments, the state's institutional structure, its ability to implement policies, the structure of social and political contention (McAdam, 1996). Social movement action is mostly launched when political opportunities are favourable to conflict due to the refusal of the political and economic establishment to proceed with changes, or alternatively when political antagonism is acute and extra-institutional social reforms are taking place.

In a system open to change, the realization that it may be responsive or susceptible to political action, and in combination with the existence of injustice and inequality, turns into political opportunity. Additionally, in case the actors of the protest do not have access to decision making centres and in the context of this deprivation they endeavour through dynamic forms of mobilization (as an unconventional means of political behaviour) to emphasize their political strength as voters by influencing those in government on the justness of their claims.

Even when the action of movements is unsuccessful, the political process continues as the discontent of their members is expressed by voting against unreliable political allies at elections. "The shifting of voters, especially when they breach established political positions reflects, in a way, their discontent at the political level but also the prospect of large-scale mobilization at times of rapid structural transformation. In this sense, differentiations in the rhetoric of political elites, and in combination with the underlying discontent, expand the capacity of mobilization and create the 
conditions for its politicization" (Serdedakis, 1996, p. 99) by aligning with opposing political groups in order to put pressure on the administration or even contribute to its political dissolution. It is primarily a political resource of movements that have no recourses other than the power of their collectivity; through their coalitions with party mechanisms they use their opposing votes in order to put pressure on the governing power.

However, claims against political authority and economic powers may exist in a form that is not necessarily contentious in a political manner, i.e. without dynamic confrontation; also, it may not be the basic element of the participants' action who often choose indirect ways to press their demands. The use of violence, even though both historically and at present, constitutes the most visible but also easiest form of collective action, its use in modern society is considered ineffective, dangerous and consequently undesirable. The reason is that it introduces conditions of a two-sided confrontation with repression mechanisms, something that most participants in movements no longer desire, society regards it as a negative example of the degeneration of social and human values, and political parties condemn it as contrary to the democratic operation. That is why most innovative movements prefer disruption - a form that could operationally be described as "threatened use of force". "Because disruption spreads uncertainty and gives weak actors leverage against powerful opponents, it is the strongest weapon of social movements" (Tarrow, 1998, p. 98). Also, social movements in most developed countries by using modern political management tools such as flexibility, compromise, reciprocal concessions, they have been altered from static subjects fighting for their demands to dynamic conventional interlocutors, i.e. a social partner with negotiating power.

According to Tilly (1999), one does not exaggerate when supporting that everything, which today is considered an institutionally established arrangement, has its roots in collective actions which at the time of their initial launch were extra-institutionally confrontational. It is therefore clear that actions of social movements promoting demands constitute a fundamental factor in shaping modern social and political reality (Tilly, 1999). This is especially true during current times that new technology, the density of international networks, the tools and speed of data and information dissemination seem to change the scenery of modern collective action. In the approach of Habermas (1981) on the effect of new movement forms ${ }^{6}$, the colonization of the lifeworld is a dominant concept. Here, movements maintain the element of the lifeworld's reaction against the dominance of the market rational and state regulation in an effort to mitigate the negative consequences of unequal resource distribution. A salient feature is the support, preservation and development of social and cultural values by the political and economic system, through appropriate communicative action, where synergy is sought. In this context new social movements may be approached as stakeholders of "resocialization" of the economy, redefinition of its operational rules, as well as of political pluralism on the basis of covering the needs of civil society.

In conclusion, it may be asserted that theories of social and political processes, and organizational analysis of social movements constitute an explanatory factor of the creation and development of the social state as an outcome of claims at a large scale. A strong unifying factor behind all theoretical approaches is their focus on the dynamics of collective action within the wider framework of social mobility and political activation theories. Tarrow (1998) states: movements emerge as a result of new or expanding opportunities, expose the weaknesses of the state against collective action, and hence open opportunities. The process leads to a response by the state, which in one way or another, generates a new structure of political opportunities and institutional transformation of society as proven by the example of the social state.

\footnotetext{
${ }^{6}$ Modern representative democracies shape the terms for the integration of movements to such an extent that today we may speak of a society of movements. This is primarily the case because: a) protest events can no longer be considered sporadic phenomena, but a concrete given of modern societies, b) the frequency of various social action forms registered is high with participants from a multitude of social strata, who present a considerably broad range of claims, and c) the processes of professionalization and institutionalization of social movements are transforming their character from a contentious form of expression to a conventional means of political claims (Meyer \& Tarrow, 1998, p. 4).
} 


\section{Epilogue}

Public space, as a terrain of political discourse, was initially limited to the early urban society and the issues of poverty and deprivation; during the industrialization of society it expanded to labour problems with measures for labour rights and safety at the workplace. Today it is expanding further to include all fields of human activity through the political and social dimension of the social state's institutional interventions. "The main political problem over the last decades is related to private life: birth and reproduction, sexuality, illness and death; they are addressed in a different way, by aiming on specialized intervention but also on individualizing action on the side of the social state" (Touraine, 1985, p. 759). Through this perspective, issues that were raised by social movements labour, student, feminist, environmental, peace, local authority, etc - are all linked to the shifting boundaries between public, private and social life and entail claims against old and new forms of dominance in these areas.

The study of collective action under the scope of interaction between social groups advocating their claims and the political system is come across in social and political theories for the creation and evolution of the social state. The critical importance of the relationship between those mobilizing and the political authorities was interpreted, among others, with the theories of collective action, resource mobilization, political process, political opportunity, but also new social movement. Based on the content of those theories it is suggested that collective action and claims, social movements, shape political response usually in the form of social policy, specialized with measures and programmes of social protection and welfare.

\section{References}

Alexandropoulos, S. (1995). Anazitontas stratigiki i taftotita: zitimata theorias ton kinonikon kinimaton [Searching for strategy or identity: Theory issues of social movements]. Epitheorisi Kinonikon Erevnon, 86, 88-113.

Alexandropoulos, S., \& Serdedakis, N. (2000). Greek environmentalism: From the statu nascendi of a movement to its integration. ECPR Joint Sessions, Workshop on Environmental Organizations. Copenhagen, Denmark.

Della Porta, D., \& Diani, M. (2006). Social Movements: An introduction. Oxford: Blackwell.

Freire, P. (1985). A pedagogy for liberation, (M. Katsoulis, Trans). Athens: Centre of Research and SelfLearning/General Secretariat of Continuing Education.

Habermas, J. (1981). Theorie des kommunikativen Handelns [Theory of communicative action], Vol. 2. Frankfurt/M: Suhrkamp.

Informationen zur politischen Bildung [Information on political education] (1992). Bundeszentrale für politische Bildung, 152, 4-48. Bonn.

Klandermans, B. (1984). Mobilization and participation: Social-psychological expansions of resource mobilization theory. American Sociological Review, 49 (5), 583-600.

Koffas, S. (2016). Kipros: Apo to modelo tis kinotikis anaptyxis tou 1960, tis kinotikis anasyngrotisis tou 1974, sto modelo anaptyxis tis evropaikis synglisis [Cyprus: From the 1960 model of community development, to the 1974 community reconstruction, to the development model of European convergence]. Kimena Periferiakis Anaptyxis, VII (1), 11-21.

Ledwith, M. (2006). Community development. A critical approach. Bristol: The Policy Press.

Meyer, D. S., \& Tarrow, S. (1998). The social movement society. Contentious politics for a new century. Oxford: Rowman \& Littlefield.

McAdam, D. (1996). Conceptual origins, current problems, future directions. In D. McAdam, J. McCarthy, \& M. Zald (Eds.), Comparative perspectives on social movements. Political opportunities, mobilizing structures, and cultural framings (pp. 23-40). Cambridge: Cambridge University Press.

Neveu, E. (2002). Sociology of social movements, (M. Logotheti, Trans.) Athens: Savvalas.

Schmidt, B. (1998). Gesellschaft der Bundesrepublik Deutschland, [Society of the Federal Republic of Germany]. In Zapf W.(Ed.) \& Schäfers B., Handwörterbuch zur Gesellschaft Deutschlands [Hand dictionary on the society of Germany] pp. 232-241. Opladen: Leske \& Budrich.

Sdrolias, L., Aspridis, G., Kakkos, N., \& Belias, D. (2013). Strategic planning of elections campaign of parliament candidate members in Greece. International Journal of Political Science, Law and International Relations, 3 (3), 11-26.

Serdedakis, N. (1996). Diadikasies paragogis ke syngrotisis ton kinonikon kinimaton: Ta nea kinonika kinimata ston elliniko kinoniko schimatismo [Processes of social movement production. New social movements within Greek society] (PhD Dissertation). University of Rethimnon, Greece. 
Serdedakis, N. (2006). I theoria gia ta kinonika kinimata ke ti syllogiki drasi. I symvoli tou Steliou Alexandropoulou [The theory of social movements and collective action. The contribution of Stelios Alexandropoulos]. Kinoniki Synohi ke Anaptixi, 1 (2), 95-103.

Tarrow, S. (1998). Power in Movement. Social Movements, Collective Action and Politics ( $2^{\text {nd }}$ ed.). Cambridge: Cambridge University Press.

Tilly, C. (1999). From interactions to outcomes in social movements. In M. Giugni, D. McAdam, \& C. Tilly (Eds.), How social movements matter (Social movements, protest, and contention). Minneapolis: University of Minnesota Press.

Tilly, C. (2004). Social Movements 1768-2004. London: Paradigm Publishers.

Touraine, A. (1985). An introduction to the study of social movements. Social Research, 52, (4), 749-787.

Wright, S.C. (2009). The next generation of collective action research. Journal of Social Issues, 65, 859-879. 